\title{
RED LEAVES AND THE DIRTY GROUND: THE CANNIBALISM OF LAW AND ECONOMICS
}

\author{
Matthew L.M. Fletcher*
}

[E]very breath that is in your lungs

is a tiny little gift to me

- The White Stripes, "Dead Leaves and the Dirty Ground"'

"We cannot eat [our slaves]."

"Why not?"

"There are too many of them."

- William Faulkner, "Red Leaves"2

\section{Red Leaves: Faulkner's Swiftian Fable of Cannibalism and Economics}

Less than a year after the stock market crash of 1929, William Faulkner moved into a dilapidated house in Mississippi. He purchased his home by putting himself deep into debt, began to fix the place up, and wrote a short story called "Red Leaves," his first story involving Indian people as characters ${ }^{3}$. He knew the land upon which the house rested was once owned by an Indian, and he knew the region was once controlled by an Indian tribe, either the Choctaws or the Chickasaws ${ }^{4}$. He marketed the short story to magazine publishers by noting that the editors probably did not know that

(C) 2009 Matthew L.M. Fletcher

* Associate Professor, Michigan State University College of Law. Director, Indigenous Law and Policy Center. Enrolled Member, Grand Traverse Band of Ottawa and Chippewa Indians. Thanks to Kirsten Carlson, Gordon Henry, Sonia Katyal, Mae Kuykendall, John Petoskey, Wenona Singel, and Sean Hill.

1. White STRIPES, Dead Leaves and the Dirty Ground, on WHITE BloOd Cells (Sympathy for the Record Industry 2001).

2. William FaUlKNER, Red Leaves, in SELECTED SHORT STORIES OF WILLIAM FAULKNER 100, 106-07 (Modem Library 1993) (1930).

3. See Robert Dale Parker, Red Slippers and Cottonmouth Moccasins: White Anxieties in Faulkner's Indian Stories, 18 FAULKNER J. 81, 84 (2002-2003) ("In April 1930, Faulkner bought a house (later called Rowan Oak), going deeply into debt despite his small income and irregular prospects.").

4. Id. at 84 (stating that Faulkner's house was built "in 1844 on land bought from a Chickasaw named E-Ah-Nah-Yea in 1836 as a direct result of Jackson's policy of Indian removal"). 
Indians had owned slaves, that this story was novel in that manner, and that he needed the money. ${ }^{5}$

"Red Leaves," one of Faulkner's more well-known stories, begins with two short, middle-aged, and paunchy Indians deliberating on the relative merits of eating the flesh of black slaves sometime in the antebellum South. Their leader, Issetibbeha, an old Indian referred to as Doom (from the French, "of the man"), who owned the slave plantation upon which the characters in the story live, had died. These two Indians are looking for Doom's manservant, a slave. Doom's son, Moketubbe, likely killed his father and will inherit Doom's wealth and power-becoming "the Man." The reason the two Indians are looking for a particular slave is that Doom cannot be laid to rest unless his most important possessions, the slave included, are with him.

Everything is wrong in "Red Leaves."

- The Indians are paunchy, short, lazy, and wear Sunday clothes, unlike the warrior-types with washboard stomachs that permeate American consciousness.

- The Indians are (or could be) cannibals, a thing that is both true and false in that many Americans believed that many Indians did eat human flesh and that some Indians apparently did eat human flesh in certain circumstances. But the Indians that came from Faulkner's region did not. $^{6}$

- The Indians own slaves, something we know was true in certain regions and circumstances, but something we know to be contrary to the character and customs of most Indian people.

- The Indians have a big boss (known as "the Man"), and the big boss's son (known as "Doom") will inherit his wealth and power (and become "the Man"). However, we know that Indians, at least those at peace, did not have big bosses who hoarded wealth or enough power to control other Indians sufficient to be referred to as "the Man."

- The Indians have a plantation, when we know the Indians of Faulkner's Mississippi succumbed to forced removal to the west after catastrophic wars with President Jackson's military. Further, we know most Indians did not have the same belief in private property.

5. Id. at 82 ("Faulkner submitted 'Red Leaves' to Scribner's magazine with a wisecracking cover letter: 'So here is another story. Few people know that Miss. Indians owned slaves; that's why I suggest you all buy it. Not because it is a good story; you can find lots of good stories. It's because I need the money.") (quoting SELECTED LETTERS OF WILLIAM FAULKNER 46-47 (Joseph Blotner ed., 1977)).

6. Duane Gage, William Faulkner's Indians, 1 AM. INDIAN Q. 27, 28 (1974). 
Of course, no twenty-first century observer can "know" for certain any of these "facts"- some of them are even disputed to this day-but these "facts" will serve as a base from which we will advance or to which we will retreat. And despite Faulkner's protestations that he never liked reading history and could not have cared less whether his representations of Indians were accurate, ${ }^{7}$ we can be sure that an intelligent man of his background and character knew most, if not all, of these problems with the accuracy of his story. As one commentator suggests, Faulkner incorporated these historical and anthropological inaccuracies into "Red Leaves" to make a point. However, it is very possible that Faulkner did not know anything about Indians. ${ }^{9}$ Regardless, it is clear that Faulkner was attempting something provocative with "Red Leaves."

"Red Leaves" begins with two Indians, Louis Berry and Three Basket, searching two slave huts for the slave, but the place is empty. ${ }^{10}$ All the slaves are hiding from these hunters. The Indians comment that this is what happened the last time "the Man"-his personal slave ran off and had to be caught. ${ }^{11}$ The last time, it appears, it took three days to catch the personal slave of the head Indian. ${ }^{12}$ The two Indians head off to look for the slave but

7. See id. at 27 ("William Faulkner's Indians are not history's Indians. They are William Faulkner's Indians, created by the artist as a part of his Yoknapatawpha saga, created from fantasy, lore, and incidental history to suit the author's needs. 'I never read any history,' Faulkner once said. 'If I got it straight it's because I didn't worry with other people's ideas about it."') (quoting Robert Cantwell, The Faulkners: Recollections of a Gifted Family, in William FAUlKNER: THREE DECADES OF CRITICISM 57 (Frederick J. Hoffman \& Olga W. Vickery eds., 1960)); Bruce G. Johnson, Indigenous Doom: Colonial Mimicry in Faulkner's Indian Tales, 18 FAULKNER J. 101, 102 (2002-2003) ("When asked what background sources he used to construct his Indian characters, Faulkner rather glibly responded, 'I made them up.' Elmo C. Howell has claimed that Faulkner knew little about the South's Chickasaw and Choctaw cultures: 'With no experience to draw upon and with his aversion to research, Faulkner makes no pretension to accuracy in his treatment of Indian life."') (citation \& footnote omitted) (quoting LEWIS M. DABNEY, THE INDIANS OF YOKNAPATAWPHA: A STUDY IN LITERATURE AND HISTORY 11 n.15 (1974), and Elmo C. Howell, William Faulkner and the Mississippi Indians, 21 GA. REV. 386, 386-87 (1967)); Parker, supra note 3, at 81.

8. See generally Peter Lancelot Mallios, Faulkner's Indians, or The Poetics of Cannibalism, 18 FAULKNER J. 143 (2002-2003).

9. See Howard C. Horsford, Faulkner's (Mostly) Unreal Indians in Early Mississippi History, 64 AM. LITERATURE 311, 312 (1992) ("[H] is sense of early Chickasaw or Choctaw life could be only hearsay and second- or third-hand at best, scarcely more even for such depressed contemporary Choctaws as may have wandered into his ken.").

10. See FAULKNER, Red Leaves, supra note 2, at 101.

11. See id.

12. See id. at 103. 
do not appear to have any interest in the chase or any skills to bring to bear. Additionally, they are hampered by the fact that Moketubbe, the grossly obese son of Issetibbeha ("the Man" who just died), will lead the hunt. ${ }^{13}$ The focus of the story shifts to the slave, who runs away but does not run far. ${ }^{14} \mathrm{He}$ visits his fellow slaves for a break and a bite to eat, but they do not want a dead man around, and so the slave moves on. ${ }^{15}$ He appears to have many opportunities to escape the area, but he stays close. At one point, he is close enough to the plantation compound (the rotting hulk of an old steamboat ${ }^{16}$ ) to see the mourners gathered around "the Man". ${ }^{17}$ The Negro has no trouble avoiding the Indians hunting for him until he is bitten by a poisonous snake and disabled. ${ }^{18}$

With "Red Leaves," there is far more than the plot. This unusual Indian community headed by a series of men called "the Man" and their sons, two men called "Doom," has for generations owned slaves. ${ }^{19}$ But the Indians living in this community do not need slaves. In fact, they do not know much about what to do with slaves. They begin to farm only because they need something for the slaves to do. ${ }^{20}$ The finest portions of the story are the sections of background where Faulkner has the Indians discuss what to do with the slaves after the first "Man" dies. One Indian suggests eating them, another part of the cannibalism motif, but that suggestion is rejected because there are too many slaves. ${ }^{21}$

Moreover, it is not certain why the original "Man" acquired these slaves, except perhaps as a means of mimicking the ways of the neighboring white plantation owners, who owned slaves. ${ }^{22}$ As one commentator noted, ownership of slaves had a certain symbolic value to white plantation owners,

13. See id. at 115-16.

14. See id. at 117-18.

15. See id. at 122 ("'Eat and go. The dead may not consort with the living; thou knowest that."').

16. See id. at 104-05 ("The front of [the house] was one story in height, composed of the deck house of a steamboat which had gone ashore and which Doom, Issetibbeha's father, had dismantled with his slaves and hauled on cypress rollers twelve miles home overland.").

17. See id. at 123.

18. See id. at 124.

19. See id. at 105-11.

20. See id. at 106 ("Doom began to acquire more slaves and to cultivate some of his land, as the white people did. But he never had enough for them to do."); id. at 107 ("“They are too valuable; remember all the bother they have caused us, finding things for them to do. We must do as the white men do."').

21. See id. at 106-07.

22. See id. at 107. 
in addition to the market value. ${ }^{23}$ While the Indians did not appear to take as much advantage of the market value of slave ownership as they could have, there was (at least for "the Man") symbolic value. ${ }^{24}$ For the rest of the Indians, there was little or no value at all-just confusion. ${ }^{25}$

For the line of Indian men known as "the Man," slaves constituted only one type of property worth possessing. Over the generations, the various "Men" acquired beds, jewelry, an abandoned steamboat, dainty red slippers, and other possessions with little or no practical (or "use") value. ${ }^{26}$ Again, it is not clear why this line of "Men" acquired these items except to somehow become more like white men with property.

Given that so much of federal Indian policy was geared toward "civilizing" Indian people, ${ }^{27}$ this should not be so surprising. But the ways that Faulkner describes Indian people becoming "civilized" are all but grotesque to white men's eyes. ${ }^{28}$ These Indians Faulkner invents have taken the worst of what American policymakers saw in American people and made those traits and customs their own. Perhaps this is the rub for Faulkner-the Indians he invents serve to show the folly of Southern society. ${ }^{29}$

But that is too easy-as we will see.

\section{The Law and Economics of Indian Law}

Law and economics is a tool of legal discourse that has been on the strong ascendancy for at least two decades. Luminaries such as Judge Richard Posner have advocated for the application of an efficiency analysis to American

23. See Karen Rhodes, The Grotesque Economics of Tragicomedy: Cultural Colonization in Faulkner's "Red Leaves", 18 FAULKNER J. 69, 75-76 (2002-2003).

24. See id. at 76 ("Having lived for a time in the market economy, Doom presumably has acquired at least its symbolic value for slaves, for he brings the first small band of pathetic slaves to the Indians.").

25. See FAULKNER, Red Leaves, supra note 2, at 107 ("When Doom died, Issetibbeha, his son, was nineteen. He became proprietor of the land and of the quintupled herd of blacks for which he had no use at all.").

26. See id. at 105-11; Rhodes, supra note 23, at 73-74.

27. See generally AMERICANIZING THE AMERICAN INDIANS: WRITINGS BY THE "FRIENDS OF THE INDIAN" 1880-1900 (Francis Paul Prucha ed., 1973); FrANCIS PAULPRUCHA, AMERICAN INDIAN POLICY IN THE FORMATIVE YEARS: THE INDIAN TRADE AND INTERCOURSE ACTS, 17901834, at 46-71 (1962) [hereinafter PRUCHA, AMERICAN INDIAN POLICY IN THE FORMATIVE YEARS].

28. See Rhodes, supra note 23 , at 69.

29. See Johnson, supra note 7, at 118 ("Faulkner uses the Indians as a metaphor for the cultural dissolution of an enslaving nation."). 
private and public law. ${ }^{30}$ The "law and econ" movement has barely touched American Indian law and policy, with a few major exceptions-and one minor, preliminary one. The first exception, more or less tangential to this discussion, is the work of economists such as Terry L. Anderson, who advocates for a less stringent federal regulatory presence in Indian Country land use decision making. ${ }^{31}$

The second exception is the scholarship about the historic dispossession of Indian land holdings. Professor Eric Kades' recent paper arguing that the purchase of Indian lands under the legal framework established in the 1763 Proclamation, ${ }^{32}$ the Trade and Intercourse Acts, ${ }^{33}$ and Johnson v. M'Intosh ${ }^{34}$-that the federal government had exclusive rights to purchase lands from Indian tribes (not individual Indians), along with a smattering of disease and cultural imperialism - was the most efficient and therefore normatively the best means of settling the American landscape is the standard-bearer in this vein of intellectual debate. ${ }^{35}$ There have been superficial attempts to apply the law and economics analysis to other areas of Indian law and policy (such as Indian gaming, ${ }^{36}$ which all but begs for the analysis), but none have had the impact of Kades' paper.

Kades' paper came at an opportune moment for law and economics scholars struggling to explain American property law when most property casebooks begin with the extraordinarily uncomfortable Indian law case Johnson $v$. M'Intosh. His presentation of the argument that efficiency dictates that it is cheaper to purchase land than to kill and destroy for it is as compelling as it is simple. Add to that efficiency the Johnson rule of the Doctrine of Discovery that only the sovereign had the right to acquire original Indian title to Indian lands and you have a doubly efficient means to settling the continent. But

30. E.g., RichARD POSNER, ECONOMIC ANALYSIS OF LAW (7th ed. 2007).

31. E.g., TERRY L. ANDERSON, SOVEREIGN NATIONS OR RESERVATIONS? AN ECONOMIC HISTORY OF AMERICAN INDIANS (1995); Terry L. Anderson \& Dominic P. Parker, The Wealth of Indian Nations: Economic Performance and Institutions on Reservations, in SELFDETERMINATION: THE OTHER PATH FOR NATIVE AMERICANS 159 (Terty L. Anderson, Bruce L. Benson \& Thomas E. Flanagan eds., 2006).

32. See 1 Francis Paul Prucha, The Great Father: The United States Government AND THE AMERICAN INDLANS 24-25 (1984).

33. See Prucha, American Indian Policy IN THE Formative Years, supra note 27.

34. 21 U.S. (1 Wheat.) 543 (1823).

35. See Eric Kades, The Dark Side of Efficiency: Johnson v. M'Intosh and the Expropriation of Indian Lands, 148 U. PA. L. REV. 1065 (2000).

36. See Paul H. Brietzke \& Teresa L. Kline, The Law and Economics of Native American Casinos, 78 NEB. L. REV. 263 (1999); Matthew L.M. Fletcher, Bringing Balance to Indian Gaming, 44 HARV. J. LEGIS. 39 (2007). 
there are even more efficiencies to consider. Individual Indian property ownership was by definition inefficient and therefore invalid. The same went for Indian tribal property ownership. Individual American property ownership was by definition more efficient than either of those. In the law and economics rubric, efficiency is enough. Efficiency is everything unless the result is absurd. The only question American property students and scholars need be concerned with after Kades' paper is understanding how we got from Indian ownership to American ownership. The answer to why is so selfevident that it is downright silly to ask the question. The leading property casebooks can now point to the Kades argument as the answer to all the property concerns raised by law students wondering about the shaky origins of American property law. ${ }^{37}$ Worried about the racism of the Doctrine of Discovery? Well, it was not racism. It was efficiency.

Kades' paper was a watershed, but in many ways it was nothing more than a presentation of the argument that had been made from the beginning by some of the Founders. Professor Ralph Lerner's 1971 paper offered a cogent historical discussion of the minds of the "white statesmen" working out of the highest offices of the United States in the earliest years of the republic. ${ }^{38}$ The Founders knew that the best conceivable policy in acquiring the Indian lands east of the Mississippi was through purchase. ${ }^{39}$ There would be absolutely nothing to gain, in the minds of the Framers, by fighting for Indian lands. ${ }^{40}$ There was no significant national debate about this question, other than how to persuade Indian people to leave their lands voluntarily. ${ }^{41}$ The 1803 Louisiana Purchase all but guaranteed that the model followed in the eastern United States would be followed west of the Mississippi as well. The real problem for these "white statesmen" lay with the ruffians occupying the borderlands of the United States and "Indian Country," those aggressive white settlers and land speculators sowing seeds of violent conflict between the Americans and the Indians. But even that question was not a terribly serious question, because after the first few decades of the nineteenth century, no one worried that the Indians east of the Mississippi would ever again constitute a military, economic, or cultural threat to the burgeoning United States. And as

37. E.g., Jesse DuKEMINIER, JAMES E. KRIER, GREGORY S. AleXANDER \& MiChaEl H. SCHILL, PROPERTY 3-9 (6th ed. 2006) (excerpting Johnson); id. at 15-16 (relying on Kades, supra note 35 ).

38. See Ralph Lemer, Reds and Whites: Rights and Wrongs, 1971 SUP. CT. REV. 201, 201.

39. STUART BanNer, How THE INDIANS LOST THEIR LAND: LAW AND POWER ON THE FRONTIER 112-21 (2005).

40. See id.

41. See id. 
Felix Cohen commented many years later, the plan generally worked. ${ }^{42}$ There are but a few acres of land the United States acquired by conquest - the United States acquired 99.9 percent of Indian lands through purchase, even if some of the purchases were less than agreeable to the Indian sellers. ${ }^{43}$

Lerner's paper is more than a foundation for the Kades law and economics analysis of Indian lands dispossession. Lerner engages in the question of the acquisition of Indian cultures as well-through the "civilizing" of American Indian people. Unlike black persons, the Founders (especially Jefferson) argued that Indian people could be salvaged from total annihilation through incorporation into American society. ${ }^{44}$ The Constitution keeps out those "Indians not taxed," but as Chief Justice Taney suggested in Dred Scott, there was the theoretical possibility of extending citizenship to other Indians. ${ }^{45}$ Not so for blacks. Lerner suggests that the relative low population of American Indians (a few thousand) compared to the hundreds of thousands of blacks made this seem palatable ${ }^{46}$, and perhaps he is right. Or as Randall Kennedy argued, "white statesmen" saw more to desire in American Indians than blacks."

Lemer's discussion of the most efficient means-from the point of view of the Founding generation-of "civilizing" American Indians is as important (if not more so) than analyzing the most efficient means of acquiring Indian lands. Kades and the law and economics analysis he undertakes all but ignores the moral question of whether Indians should be dispossessed of their lands. Lerner documents the intellectual struggles of the "white statesmen" who knew that the United States and its citizens would one day possess all Indian lands but worried about the nation's moral standing with the world if America acquired Indian lands through extermination of Indian people. ${ }^{48}$ While hardly a benevolent notion in retrospect, the policy of "civilizing" American Indians - for Lerner-was the result of a good-faith effort of the Founders to

42. See Felix S. Cohen, Original Indian Title, 32 MINN. L. REV. 28 (1947).

43. See id. at 33-34.

44. See Francis PaUl Prucha, AMERICAN INDIAN POLICY IN THE Formative YeARS: ThE INDIAN TRADE AND INTERCOURSE ACTS, 1790-1834, at 211-19 (1962).

45. See Scott v. Sanford, 60 U.S. (1 How.) 393, 403 (1856) ("[The Indian race], it is true, formed no part of the colonial communities, and never amalgamated with them in social connections or in government. But although they were uncivilized, they were yet a free and independent people, associated together in nations or tribes, and governed by their own laws.").

46. See Lerner, supra note 38, at 229.

47. See RANDALL KENNEDY, INTERRACIAL INTIMACIES: SEX, MARRIAGE, IDENTITY, AND ADOPTION 482-84 (2003).

48. See Lerner, supra note 38, at 219-21. 
prevent the total annihilation of Indian people. ${ }^{49}$ It was this policy-a wild, wishful hope (and fear) that some Indians would become "civilized," take up the mantle of American values, adopting an agrarian society, a written rule of law, a system of law and order, and a written language - that confounded the Founders. It confounded the Founders because some tribes and some Indian people did exactly as they were told and as they promised-the Cherokee Nation in Georgia being the prime example. These Indian people then expected the "white statesmen" to follow through with their end of the bargain. The "white statesmen" in D.C. had gambled that no Indian community would become "civilized" as they defined that term in the late eighteenth and early nineteenth centuries. In fact, for all practical purposes, all Indian tribes that survive to the present day have become "civilized."

Where Kades stumbles (and even Lerner underestimates, in my view) is in considering the irrationality of Lerner's "white statesmen," with the State of Georgia and President Jackson being the standard-bearers of irrationality. Kades cannot argue that irrational aspects of nineteenth century Indian law and policy-namely, Indian removal-were efficient. Indian removal was a product of a sort of nationwide mob rule and wholly inefficient in the manner defined by Kades (that is, Machiavellian). But then again, irrationality is the major weakness of any law and economics analysis.

In short, the major problem for the Founders was the possibility that American Indians would play their game and win. Faulkner's Indians in "Red Leaves," no matter how strange or grotesque, played the game and won.

\section{The Law and Economics of Cannibalism}

\section{A. Cannibalism and Red Leaves}

Cannibalism is the critical element of "Red Leaves" as part of the opening of the story with the two Indians discussing the relative flavor of black flesh-the flesh of persons made to sweat-as compared to the flesh of animals hunted and cooked for food. Three Basket, the older of the two Indians, notes that slavery is not the "old way," which was the "good way." Louis Berry comments that Three Basket is not old enough to even remember the "old way," but Three Basket argues that he has talked to those who are old enough to remember. ${ }^{50}$ Here, then, is an important dating of the story. The Indians who own a large plantation and who own slaves identify the "old

49. See Id. at 202.

50. FAULKNER, Red Leaves, supra note 2, at 102. 
way"-Indian lifeways before slavery-as better than their current lifeway. But they have not lived during the period of the "old way." These Indians note that hard work on the farms involving too much sweat and too much sun is no good. Regardless, there they are, overseeing the work and sweat of the slave plantation for reasons they do not understand very well.

The history of "the Man's" plantation described by Faulkner adds an additional element of depth to the problem of Indians owning slaves (forgetting for the moment the inherent problem of slavery). The Man brought these slaves to this Indian community for their "symbolic value," as one commentator argued, not their "use value" or "market value." community here has no need or desire to own slaves, but they have somehow acquired and live upon a plantation. There is a simple algebra at work. Whites who own plantations also own slaves. Indians who wish to remain in the vicinity and avoid "removal" must become like whites. So these Indians must find some way to own a plantation. Only a rich man can own a plantation and, somehow (again), these Indians find a rich man amongst themselves to acquire a plantation. And, if this rich Indian owns a plantation, he must act like the whites do and own slaves. This, at least, is how "the Man" behaves, whether he knows it or not. The other Indians living in this community-a plantation that seems to have become a kind of Indian community, even a reservation-do not buy into the notion of a slave plantation, but they buy into the notion of remaining in this area. So they buy into the notion of a rich Indian who owns a slave plantation as a means of remaining in the area.

If the setting of "Red Leaves" is placed in the context of the structure of federal Indian law and policy of the nineteenth century, what Faulkner has created is a small Indian community that has adopted the ways of the white man-not completely, but in a manner sufficient to avoid removal. It is a "new way" for these Indians to live, perhaps no better than the "new way" of the Indians removed to the west or the Indians who went underground (like the Poarch Band of Creeks or the Florida Seminoles) or even the Indians who died, but it is their "new way."

The conflicts between this "new way" and the "old way" create a social, political, and economic friction that causes these Indians to consider and even practice cannibalism. Critical literature focuses on whether Faulkner knew that the Indians in that region practiced cannibalism because the anthropological studies show that they, in fact, did not. ${ }^{52}$ But consider the

51. See Rhodes, supra note 23 , at 69.

52. See Mallios, supra note 8 , at 148 . See generally Gage, supra note 6 . 
possibility that a real Indian community, over the course of hundreds of years, facing an onslaught of disease and violence created by the arrival of Europeans, may resort to cannibalism in certain circumstances as a means of reacting to and responding to these ongoing and overwhelming threats and changes. Great Lakes Ottawas, for example, had been shown to practice a form of cannibalism and torture of prisoners when confronted with the violent assaults of Haudenosauneedenosaunee that drove them out of their homelands ${ }^{53}$ (the Haudenosaunee themselves, of course, were pushed to invade the territory of others by the impacts of Europeans on their own communities). ${ }^{54}$ Perhaps these cannibalistic Ottawas did these things because their entire social and political structure was destroyed by this violence, so much so that they moved across Lake Michigan to the Green Bay area, where they were forced to live for the better part of a century. ${ }^{55}$ It is just a theory.

So perhaps Faulkner did not care whether these Indians did or did not practice cannibalism in real life because it was not a part of their customs, traditions, or lifeways. Perhaps Faulkner was more concerned about whether these Indians could have practiced cannibalism if they faced a set of circumstances that might have rewarded cannibalism in some way. Perhaps he was more concerned about exploring the circumstances that would incite non-cannibal Indians to become cannibals (or at least to consider it).

The earliest chronological consideration of cannibalism in "Red Leaves" is not where Three Basket discusses the taste of black flesh, but in the background story of "the Man" bringing slaves to the community in the first place. The Indians living there had no idea what do to with the slaves and, at that point, consider the possibility of eating them. There are reasons not to do so, namely that there were too many people to eat and "that much flesh diet is not good for man." ${ }^{\text {"In }}$ Intead of eating the slaves, or even killing them, they grudgingly put the slaves to work. Of course, the Indians do not manage their slave plantation any better than the worst white slave plantation owner, practically running it into the ground. Some commentators have implied that Faulkner's description of how incompetent these Indians are at operating their slave plantation is an observation of how white slave plantation owners were

53. See RICHARD WHITE, THE MIDDLE GROUND: INDIANS, EMPIRES, AND REPUBLICS IN THE GREAT LAKES REGION, 1650-1815, at 231 (1991).

54. See HELEN HoRnBaCK TANNER, ATLAS OF GREAT LAKES INDIAN History 29 (1987).

55. See Charles E. Cleland, RItes of Conquest: The History and Culture of MiCHIGAN's NATIVE AMERICANS 92-98 (1992).

56. FAULKNER, Red Leaves, supra note 2, at 107. 
incompetent as well, running an entire social and economic structure into the ground. ${ }^{57}$ But there is more.

Here, these Indians who have played (and won) the white man's game of avoiding removal consider cannibalism first before other possible solutions to the slave problem. Of all things to consider, right? In short, the Indians who have followed in the footsteps of the white man, taken up plantation living, and acquired slaves, consider cannibalism as a possible course of action when they are not sure what to do with them. Commentators have argued that Faulkner's Indian cannibals parallel the white slave owners in the sense that this entire economic system is flawed from the ground up. Again, like the previous line of commentary, this argument assumes Faulkner was using the Indians he created to critique Southern culture and society. He may have been doing that. But when it comes to cannibalism, there is so much more at stake.

\section{B. The Import of Cannibalism as a Theoretical Matter}

Consider cannibalism.

Cannibalism has been used as a literary and critical technique to analyze Western and non-Western society and culture dating at least as far back as Montaigne's "On Cannibals." 58 It has been used as a means of depicting both sameness and difference, rendering cannibalism as an analytic tool.

In one vein, the Westerners watching, intervening, and interacting with the New World cultures see cannibalism at every turn. Westerners see difference in the cannibal as savage and even use this difference as a justification for the subjugation, dispossession, or even annihilation of indigenous peoples. ${ }^{59}$ These savage cannibals - a common descriptor of the inhabitants of the New World for centuries-are to be feared and loathed. They lack civilization, religion, and even "breeches." These people are little better, or even no better, than animals. These people eat human flesh. Sometimes they eat flesh as a means of terrorizing adversaries, sometimes they eat flesh for ceremonial purposes related to war or religion, and sometimes they eat human flesh because they are simply so savage that they enjoy it.

In a second sense, what C. Richard King, following Dean MacCannell, calls "neocannibalism," cannibalism is used as a tool of analysis to critique Western

57. E.g., Johnson, supra note 7, at 118.

58. MONTAIGNE, On Cannibals, in 1 EsSaYs OF MONTAIGNE 207 (Charles Cotton, trans. 1902) (1580).

59. See David E. Stannard, American Holocaust: The ConQuest of THE NeW WORLD 197 (1992). 
culture. ${ }^{60}$ Montaigne's "On Cannibalism" and Swift's "A Modest Proposal" use cannibalism as a means of critiquing Western culture. ${ }^{61}$ This kind of cannibalism is not necessarily literal and suggests a reversal of the labeling of a people as cannibals. Here, it is not the savage, indigenous cannibal that is being critiqued, but the Western culture that is cannibalizing the New World. There might not even be a literal cannibal, but as in Montaigne's essay, there is a bountiful and tasty continent, populated with beautiful and innocent people and full of food, drink, song, and useful resources. Here, the cannibals are not the savages, but the invaders and conquerors. And they do not even realize it.

There are many spinoffs of Montaigne's original thought permeating the literature of critical theory, perhaps too many. King's commentary on "neocannibalism," for example, is not positive. He critiques Jack Forbes and others on the overuse of cannibalism as a tool, as well as the shoddy methodology of its users. According to King, the employers of "neocannibalism" essentialize both "the West" and "the Other," or Indians. ${ }^{62}$ There is no one "Western" mind, just as there is not one simple "Indian" mind. But these are mere quibbles in the context of the greater theory. Perhaps Forbes and others overstate the theory, but Montaigne, Swift, and Faulkner suggest that there is something important to consider here. There is nothing wrong with non-Indians looking at their "cultural patrimony" (to borrow David Treuer's term) ${ }^{63}$ as did Faulkner or Montaigne. But it seems as if King will not have it if Forbes, or others outside of the non-Indian cultural and critical tradition, make this argument. But that is not very important here.

Finally, in yet another sense, one more important to this paper, the Indians mirror Western civilization by engaging in what they see as a fundamental tenet of Western civilization - cannibalism. In this sense, the "savages," the "infidels," and the Indians who otherwise are not cannibalistic take up the culture of the Westerners or the "civilized," abandoning their own traditions and lifeways, and acquire a tendency to become cannibals in a literal sense. Faulkner's cannibal Indians in "Red Leaves" are not cannibals and do not consider cannibalism until they adopt the ways of the white man. It would appear that here, as has been shown in the context of other colonial contexts, the Indians adopt a taboo activity (here, cannibalism) as a means of following

60. C. Richard King, The (Mis)uses of Cannibalism in Contemporary Cultural Critique, 30 DIACRITICS 106, 113 (2000) (quoting DEAN MACCANNELL, Cannibalism Today, in EMPTY MEETING Grounds: THE TOURIST PAPERS 20 (1992)).

61. See id. at 110 (citing Swift and Montaigne).

62. See id. at 115-17.

63. David Treuer, Native American Fiction: A USER's Manual 202 (2006). 
or adopting a "superior" cultural trait. In some contexts, cannibal Indians even abandoned the practice of cannibalizing prisoners of war when they saw their cultural "superiors," the Portuguese, engage in torture and brutal destruction of living and dead enemy bodies. ${ }^{64}$

How does this theoretical framework play out in "Red Leaves"?

\section{The Cannibalism of Law and Economics}

\section{A. The Cannibalism of the "White Statesmen"}

Faulkner's "Red Leaves" engages a subject matter-a kind of individual story character and a community composed of these characters - that had long been ignored in the American literary tradition. These persons are the Indians left behind, so to speak, or as I phrased it above, the Indians that "won." To describe these persons and communities, one must assume that we could characterize the boundary line formed by the King of England in 1763 dividing the Colonies from "Indian Country" as a tangible, political reality, a boundary line that moved with inexorable slowness west until it finally engulfed all of Indian Country except for the few Indian reservations that remained. The Indians (and even some Indian communities) that existed after this boundary line passed over them are Faulkner's subject matter for "Red Leaves." In real life, examples of this kind of Indian community would be the temporary existence of the Cherokee Nation in Georgia, Tennessee, and North Carolina after the Treaty of Hopewell in 1795 until removal in the $1830 \mathrm{~s} ;{ }^{65}$ the New England praying town composed of what is now referred to as the Stockbridge-Munsee Community removed in the nineteenth century to Wisconsin; ${ }^{66}$ or the Pokagon Band of Potawatomi Indians that adopted the white man's religions to avoid removal (the only tribe of this group of three to do so successfully over time). ${ }^{67}$ These Indians stubbornly resisted removal and, in many circumstances, adopted as best they could the ways of the white man to fit in with the new political and social realities.

64. See MONTAIGNE, supra note 58, at 248.

65. See ANTHONY F.C. Wallace, THE LONG BItTER TraIl: ANDREW Jackson AND the INDIANS (1993).

66. See Lion G. Miles, The Red Man Dispossessed: The Williams Family and the Alienation of Indian Land in Stockbridge, Massachusetts, 1736-1818, 67 NEW ENG. Q. 46 (1994).

67. See James A. Clifton, The Pokagons, 1683-1983: Catholic Potawatomi Indians OF THE ST. JOSEPH RIVER VALIEY (1984); R. DAVID EDMUNDS, THE POTAWATOMIS: KEEPERS OF THE FIRE 266, 274 (1978). 
The Founding generation-or as Lerner called them, "white statesmen"-included in its ranks intellectuals who had great concern for this class of persons. As the Constitution itself suggests, the Founders had little concern for the Indians on the other side of the line, who they considered foreigners not subject to their reach or concern-hence, the Indian Commerce Clause (or the Treaty Clause and the War Powers). The Founders worry for the Indians on or near the line, the ones engaging (and often fighting) those barbarian whites seeking land, glory, and economic value, satisfied that the federal government's war and treaty powers would handle those questions. The Founders were aware of the Indians left behind the line by refusing to count them (at least some of them anyway) in the Indians Not Taxed Clauses. But they did not know what to do with these Indians, likely believing that their fate would be one of two choices (or fates): extinction or assimilation. Some Founders, as Lerner argues, had moral concerns about the Indians left behind that would go extinct, but those concerns would be allayed if the "white statesmen" made a good-faith effort to help them assimilate. If these efforts failed, at least the "white statesmen" tried, and the failures would be placed at the feet of dead Indians.

But what of the Indians that did assimilate, that did succeed in taking advantage of what little advantage the "white statesmen" left for them? Could they become citizens and vote? The Supreme Court in Dred Scott seemed to think so, or at least Chief Justice Taney said so to make a point about blacks (who could not). ${ }^{68}$ What was their fate?

Well, history answered that-“"removal," "assimilation," and in some cases "murder." The Indians left behind who played the game presented to them by the "white statesmen" still lost. The United States subjected the Cherokees to the Trail of Tears and the Creeks and Seminoles to the last of the Indian wars east of the Mississippi. ${ }^{69}$ Out west, the Americans would subject the California and Colorado Indians located behind the lines to mass slaughter. ${ }^{70}$ The United States would continue to employ its vicious policy against the Indians who won in the latter nineteenth and early twentieth centuries by stealing Indian children and sending them to boarding schools to have their

68. See Scott v. Sanford, 60 U.S. 393, 404 (1856).

69. See SEAN Michael O'BRIEN, IN BITTERNESS AND IN TEARS: ANDREW JACKSON'S Destruction of the CREEKS AND SEMINOLES (2003); Alfred A. Cave, Abuse of Power: Andrew Jackson and the Indian Removal Act of 1830, 65 HISTORIAN 1330 (2003).

70. See J. Nixon Hadley, The Demography of American Indians, 311 ANNALS 23-24 (1957) (California massacres); Katie Kane, Nits Make Lice: Drogheda, Sand Creek, and the Poetics of Colonial Extermination, 42 CULTURAL CRITIQUE 81, 82 n.1 (1999) (collecting studies on the Colorado massacres). 
cultures and languages annihilated and by otherwise exploiting the lands of the resource-rich Indian communities that won."1

Professor Kades argued that the most efficient—and therefore best—policy of dealing with the Indians in the first generations of Indian affairs policy was to purchase their lands and drive them back with a passive-aggressive campaign of disease, dependency, and starvation, keeping Indian wars to a minimum. ${ }^{72}$ Assuming this characterization of Indian affairs is accurate (which I doubt), it could not have been perfect. As Faulkner asserts by elevating the Indian savages to Indian citizens in "Red Leaves," there were some exceptions, some Indians who avoided this "efficient" program. The "white statesmen" that Kades elevates to maximizers (in the economics lingo) had to deal with the inscrutable problem of these Indians who won. Purchase of their lands would not work because they were not selling or perhaps because their lands were protected from alienation by treaty or federal statute.

What is an efficient "white statesman" to do? Well, as general and then President Jackson demonstrated, if efficient purchase is out of the question, then Machiavellian war, murder, coercion, and other vicious, ugly policy choices became the most efficient. Keep in mind that the underlying goal of all this increasingly inefficient Indian affairs policy was the eradication of Indian people from the sight and convenience of the Americans. For the most part, as Professor Kades demonstrated, the efficiency programs worked. But the exceptions were significant - and constitute the entirety of Indian Country in this modern era.

\section{B. The Cannibalism of Modern America}

Federal Indian policy changed from a program of forced assimilation and removal starting in the 1930s, stalling in the 1950s and 1960s, and starting up again in the 1970s. What to do with these inefficient Indians and tribes?

The question remains unanswered to this day. Since 1959 (the year Charles Wilkinson began the modern era of federal Indian law), ${ }^{73}$ Indians and tribes have turned to the federal judiciary to enforce their rights under all those Indian treaties and federal statutes designed to efficiently dispossess Indian tribes and assimilate Indian people. As federal law-especially the Supremacy

71. See Bill Dunlop, THE Indians of Hungry Hollow 131-40 (2004); AMElia V. KATANSKY, LEARNING TO WRITE "INDIAN": THE BOARDING-SCHOOL EXPERIENCE AND AMERICAN INDIAN LITERATURE (2005).

72. See generally Kades, supra note 35 .

73. See Charles F. Wilkinson, american Indians, Time, and the Law: Native SOCIETIES IN A MODERN CONSTITUTIONAL DEMOCRACY 1 (1987). 
Clause-has proven, the United States had to give something up in exchange for tribal lands and property. ${ }^{74}$ It was not much-and in some instances it was downright unconscionable ${ }^{75}$ - but tribes retained whatever it was that they bargained for in those treaties and other agreements: on- and off-reservation hunting, fishing, and gathering rights; rights to inalienable property; water rights; mineral rights; and a "special relationship" with the federal government. The rule of law precludes these rights from disintegration through the passage of time or the pressures of politics. But once a cannibal tastes or smells flesh, it must consume.

The rule of law of federal Indian law contains a weak link-it is not codified in the Constitution. Federal Indian law is federal common law--subject to the manipulations and even reversal by the United States Supreme Court. Prior to the modern era, the Court was not above holding against tribal interests and construing federal Indian law as it wished. The Kagama case is the prime example, where a strict constructionist Supreme Court could not find congressional authority to enact criminal laws in Indian Country in the Constitution, but held that the authority must be there somewhere. $^{76}$

The Rehnquist Court (and now, presumably, the Roberts Court) began to take advantage of this weak link in the late 1970s with the triad of cases decided in the 1977 Term-Santa Clara Pueblo v. Martinez, ${ }^{77}$ Oliphant $v$. Suquamish Indian Tribe, ${ }^{78}$ and United States $v$. Wheeler ${ }^{79}$ exemplifying this

74. See generally Minnesota v. Mille Lacs Band of Chippewa Indians, 526 U.S. 172(1999); Washington v. Wash. State Commercial Passenger Fishing Vessel Ass'n, 443 U.S. 658 (1979); Lac Courte Oreilles Band of Lake Superior Chippewa Indians v. Voigt, 700 F.2d 341 (7th Cir. 1983); United States v. Michigan, 471 F. Supp. 192 (W.D. Mich. 1979); United States v. Washington, 459 F. Supp. 1020 (W.D. Wash. 1978), aff'd, 573 F.2d 1123 (9th Cir. 1978); United States v. Washington, 384 F. Supp. 312 (W.D. Wash. 1974), aff'd, 520 F.2d 676 (9th Cir. 1975).

75. Consider that the United States purchased about one-half of the land in the State of Michigan for twelve and one-half to thirteen cents per acre. See United States v. Michigan, 471 F. Supp. 192, 226 (W.D. Mich. 1979) ("The dominant motive appears to have been to cheat the Indians out of their lands and reduce their holdings to the reservations. Thereby the Indians would be deprived of their natural habit of roaming the range of the lands on their summer and winter migrations. Thereby the Indians would be deprived of their lands before they realized their eventual value. The figure received for the land 12-1/2 - 13 cents per acre indicates that the Indians were cheated out of their land.").

76. United States v. Kagama, 118 U.S. 375, 384-85 (1886).

77. 436 U.S. 49 (1978).

78. 435 U.S. 191 (1978).

79. 435 U.S. 313 (1978). 
new and aggressive form of judicial supremacy.$^{80}$ Just as Congress and the Executive branch turned around its programs favoring dispossession and assimilation, the Supreme Court has reversed its own course of upholding the rule of law.

The Court's program is far from complete. One (sort of) advantage tribal interests have is the increasing amount of standardized "settled law" that the Court has articulated. Lower courts need only apply the Court's doctrines. So long as lower courts do not make new federal common law, the Supreme Court will yawn at the Indian cases-as the Roberts Court has been since $2005{ }^{81}$ But the last major Indian law case decided by the Court-City of Sherrill $v$. Oneida Indian Nation ${ }^{82}$ _exemplifies the taste for flesh apparent in the federal judiciary. In that case, the Court drew upon an 1892 case $^{83}$ as authority for the dispossession of the governmental rights of the Oneida Indian Nation, ignoring a 1922 case $^{84}$ that supported the tribal claims. Here, the Court consumed the legal rights of the Oneida Indian Nation-and perhaps all the New York tribes-without a serious legal argument except the relative inefficiency of recognizing an additional governing body in the Indian Country of the Oneida people.

And that is the rub of the cannibalism of law and economics, a method of study and legal analysis that is beginning to rear its ugly head in Indian affairs once again. For what is less efficient to non-Indians than the existence of Indian tribes and Indian people competing for resources and authority?

80. For more detail about the import of this trio of cases, see Ezekiel J.N. Fletcher, Trapped in the Spring of 1978: The Continuing Impact of the Supreme Court's Decisions in Oliphant, Wheeler, and Martinez, FED. LAW., Mar./Apr. 2008, at 36.

81. This was written right before the Roberts Court granted cert in and decided Plains Commerce Bank v. Long Family Land and Cattle Co., 128 S. Ct. 2709 (2008); and Carcieri v. Salazar, 129 S. Ct. (2009). The Court has also granted cert and likely will reverse lower court victories for tribal interests in United States v. Navajo Nation, No. 07-1410 (U.S. argued Feb. 23, 2009), and Hawaii v. Office of Hawaiian Affairs, No. 07-1372 (U.S. argued Feb. 25, 2009). See Commentary on the Navajo Nation Oral Argument: Posting of Matthew M.L. Fletcher to Turtle Talk Blog, http://turtletalk.wordpress.com/2009/02/24/commentary-on-thenavajo-nation-oral-argument/ (Feb. 24, 2009, 9:40 a.m.); Commentary on the Hawaii v. Office of Hawaiian Affairs Oral Argument: Posting of Matthew M.L. Fletcher to Turtle Talk Blog, http://turtletalk.wordpress.com/2009/02/26/commentary-on-the-hawaii-v-office-of-hawaiianaffairs-oral-argument (Feb. 26, 2009, 9:39 a.m.).

82. 544 U.S. 197 (2004).

83. Felix v. Patrick, 145 U.S. 317 (1892).

84. Ewert v. Bluejacket, 259 U.S. 129 (1922). 


\section{Faulkner's Brilliance or Savagery?}

William Faulkner, perhaps without knowing, recognized an interesting strand of law and policy that is beginning to dominate Indian affairs-the cannibalism of Indian tribes.

The Indians in "Red Leaves" are cannibals—perhaps. Faulkner may or may not have thought they were (the Chickasaws and Choctaws, anyway), but they owned slaves, and that is in many ways the same thing. He wrote about Indians who adopted the ways of the white man-all the worst ways: slavery, sloth, greed, murder, and (although Faulkner was being more opaque in making this argument) cannibalism. These are the Indians who survived the westward line of American expansion-the same Indians who tend to personify modern Indian tribes. Here is Faulkner's savagery-attributing cannibalism to a made-up culture of Indians as a means of critiquing American (or at least Southern) brutality.

But what of the real Indians, the ones who survived that first wave in the East and then the rest of it, 200 years worth and counting? Does Faulkner's critique extend to the Indians of the modern era? Indians and non-Indians alike victimized in some way (either in fact or perception) would find a great deal of agreement in the notion that Faulkner's critique of white culture through the use of fictional Indians could also be applied to modern Indian tribes and people. Have modern Indian tribes not started up bingo halls and slot machine palaces? Do modern Indian tribes not employ Indians and nonIndians alike in smoky casinos, paying surf (as opposed to slave) wages while denying these employees access to the protections of federal and state employment laws? Do these tribes not hide behind sovereign immunity when confronted with a case they do not want to litigate? Where is tribal culture? Have they used their "special relationship" with the United States and their inherent sovereignty to make a buck? How are they different-really-from the Indians in "Red Leaves"?

Faulkner was not that smart. And like the Congress of the 1930s, the Faulkner of the 1930s never would have predicted tribal gaming revenues reaching $\$ 25$ billion a year. Even if he were knowledgeable of Indian affairs (maybe he was, who knows?), he would not have predicted treaty fishing cases or wealthy mining tribes or anything like these.

But Faulkner assigned to his fictional "Red Leaves" Indians a special place in American literature. These Indians represent, in no uncertain terms, the moral core of American society. The slave owners of the South who really thought about slavery knew it was wrong, knew it was racist, and may have known it was economically inefficient. But of course, they did not stop until 
they lost a major war that destroyed their society and economic system. Indians - even Faulkner's fictional Indians-knew what it was like to lose wars and to lose everything from their property to their cultures to their lives. The South did not know it yet, and America in general has only had a little taste (for those foreign wars were just that). Faulkner's fictional Indians were going to stop owning slaves and reject the whole disgusting business-not in "Red Leaves", maybe, but soon after. In fact, these Indians had been openly questioning slavery for years, debating and considering it, and seeing the wisdom of ending its practice.

And that is what Indian tribes and Indian people do in the modern era as well (not exclusively, of course). Indian tribes are on the forefront of the climate change debate-as well they better, because hundreds of Indian nations stand to lose their entire land base to the seas. ${ }^{85}$ Indian tribes are reconsidering critical legal and policy questions like criminal justice, restorative justice, employee rights, land uses, environmental protections, and virtually every conceivable public policy question. Why? They are the youngest type of government in the United States-everything is a question of first impression. That puts Indian tribes at the forefront, far ahead of state and local governments - and a million light years ahead of the lumbering behemoth known as the federal government. All these governments have confronted most of these questions before (except climate change), and they are set in their ways. All these governments do now is take the old rules and tweak them in a vain attempt to not change anything significant. Indian tribes are not as constrained.

And that is where Faulkner succeeded, in looking for an outlet for the staid society that changes little or not at all. And he found it by creating a fictional band of Indians - cannibalistic, lazy, fat, and ridiculous in every way, but progressing in fits and starts in a manner not conceived of by the whites.

85. Cf. Complaint, Native Village of Kivalina v. Exxon, No. 08-1138 (N.D. Cal., Feb. 26, 2008), available at http://turtletalk.wordpress.com/2008/02/28/native-village-of-kivalina-vexxon-complaint/ (last visited Apr. 30, 2008). 